\title{
Apple allergens as affected by cultivation technolog and variental factors
}

\author{
Takács, K. ${ }^{1}$, Szamos, J. ${ }^{1}$, Szabó, E. E., Szabó, Z. ${ }^{2}$, Nyéki, J. ${ }^{2}$ \& Gelencsér, É. 1 \\ ${ }^{1}$ Central Food Research Institute, Herman Ottó út 15., H-1022 Budapest (k.takacs@cfri.hu) \\ ${ }^{2}$ Centre of Agricultural Sciences and Engineering, University of Debrecen, \\ Böszörményi út 138, H-4015 Debrecen, Hungary
}

\begin{abstract}
Summary: Our objective was to study the effect of organic farming and area of cultivation on the allergen content of apple varieties by quantification of the major allergens (Mal d 1 and Mal d 2) using allergen-specific ELISA. The obtained results showed that except Idared IX. 29. most of examined varieties, when cultivated under organic farming conditions, contained lower level of Mal d1 allergen than those produced with integrated farming. The different varieties were found to vary substantially in their Mal d 1 allergen content. Furthermore, with some varieties the area of cultivation affected to some extent the content of Mal d 1 allergen.
\end{abstract}

Key words: apple, allergy, protein, ELISA

\section{Introduction}

Consuming apple is involved in a healthy, well-balanced menu, nevertheless for some people - mostly in Centre - and North Europe - it is meant to be a source of allergens. Fruit allergy is an adverse reaction to the consumption of fruit, mediated by an IgE-response and manifested through pathophysiological response to food (Hoffmann-Sommergruber, 2000). IgE-mediated food allergies have two phases, the first involving sensitisation, where an IgE-response is generated towards a target antigen. The second phase occurs on re-exposure to an allergen when an allergic reaction takes place as pre-existing IgE binds the target macromolecules, triggering the release of histamine and other inflammatory mediators (Mills \& Breiteneder, 2005). Allergy to apple is highly associated with IgE-mediated hypersensitivity to birch pollen (birch-apple syndrome). Most of the appleallergic patients suffer from local symptoms (i.e. oral itching, tingling, angioedema of the throat), which occur within minutes after ingestion of native apples. In highly sensitized patients, only one bite of apples is sufficient to elicit an allergic reaction (Vieths et al., 1993). The minimal allergen dose, which evokes clinical symptoms, is still not defined. The major proteins in apple are the Mal d $1(17 \mathrm{kDa}$, heat labile on room temperature, Bet v 1-homologue, a PR-10 plant protection protein) and the Mal d $2(31 \mathrm{kDa}$, thaumatinlike protein, strongly stable on room temperature). The level of allergen (protein) varies with the type (varieties) of apple and its maturity (ripeness). Apples in stores had higher levels of allergen than freshly picked fruit (www.allallergy.net).

The main objective of the present work was to achieve a comparative study on quantification of the major allergens (Mal d 1 and Mal d 2) of different apple species and to characterize the effect of cultivation condition on the apple allergens.

\section{Materials and methods}

\section{Materials}

Apples were obtained both from the Research Institute for Fruit Growing and Ornamentals of Újfehértó (Ú) and the Experimental Farm and Study Farm of the University of Debrecen in Pallag (belonging to Center of Agricultural Sciences and Engineering of the University of Debrecen) (P). Apples were harvested in the year of 2009 on that day signed next to the apple-name by the following. The apple varieties grown both under organic farming and integrated cultivation conditions are: Remo IX. 1. (Ú), Prima (Ú), Remo IX. 1. (P), Topáz IX. 29. (Ú), and Idared IX. 29. (P), while those grown with integrated cultivation conditions are: Rebella IX. 1. (Ú), GálaMust VIII. 26. (P), Rajka IX. 1. (Ú), Rewena IX. 29. (Ú), Florina IX. 29. (Ú), Idared X. 7. (Ú) and Red Idared X. 7. (Ú). From every variety a batch of about $20 \mathrm{~kg}$ was harvested and duplicate samples of 5 apples from each were randomly taken for analyses.

Mal d 1 protein previously purified by multi-step chromatographic methods, as antigen, were supplied by the Central Food Research Institute for producing of Mal d 1 antibodies.

\section{Preparation of samples and purification of soluble fraction}

Seedless apples (pulp with peel) were cut into small pieces fast as far as possible to avoid the sudden browning, 


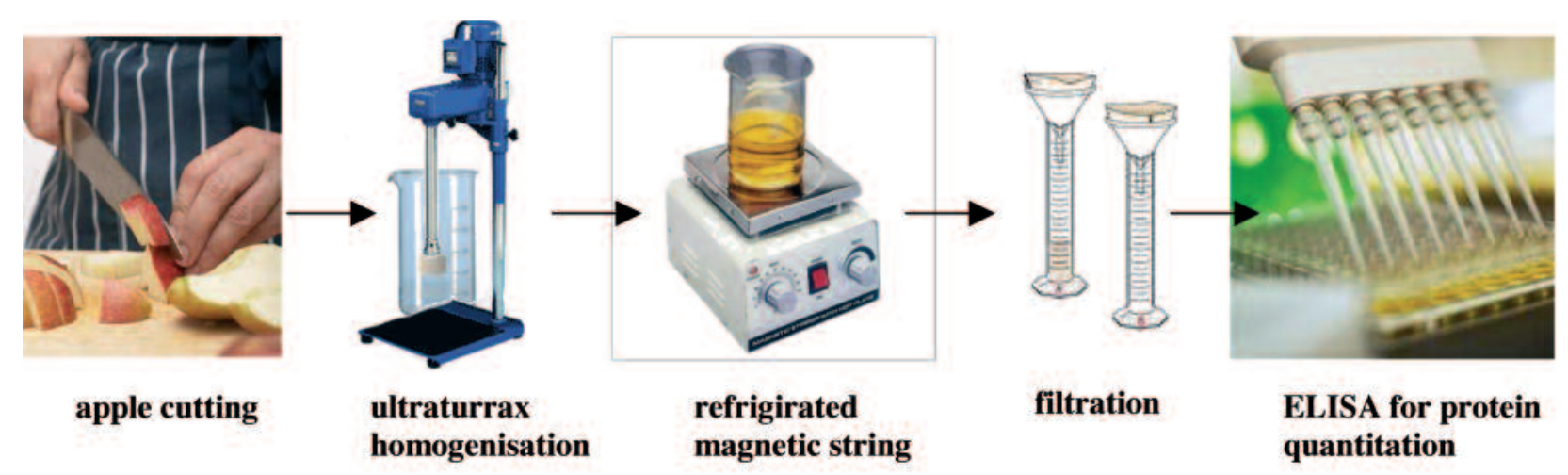

Figure 1. Scheme showing apple proteins preparation and quantification Quantification of Mal d 1 by ELISA with the developed Mal d 1 antiserum

and then frozen at $-25^{\circ} \mathrm{C}$. The frozen apple pieces were ground by masticator then mixed to be homogenized. $100 \mathrm{~g}$ out of the homogenized material was completed for the extraction with $200 \mathrm{ml}$ of $20 \mathrm{mM}$ citrate-phospate buffer ( $\mathrm{pH} \mathrm{3.0)}$ and $2 \%$ of polyvinylpolypyrrolidon (PVPP), then further homogenized with ultraturrax. The procedure of extraction was made at $4^{\circ} \mathrm{C}$ for an hour. Furthermore the homogenate was filtered through a nylon cloth, then centrifuged at 10 000xg for $10 \mathrm{~min}$ and the apple extract was collected. For ELISA analysis, $\mathrm{pH}$ of the extract was adjusted to neutral value with saturated $\mathrm{Na}_{2} \mathrm{HPO}_{4}$. Preparation and determination of protein fraction containing apple allergens is illustrated in Figure1.

After an appropriate extraction procedure, examination was carried out by Mal d 1 protein-specific ELISA (Tijssen, 1985 ) with the use of Mal d 1-specific polyclonal antibodies produced in rabbit (Harboe \& Inglid, 1973).

\section{Results and discussion}

Mal d 1 is one of the major allergen families in apples and to measure its quantity should be important for us. In this study, the focus was rather to monitor and compare the effect of the different type of cultivation technology with special regard to Mal d 1 allergen proteins. The measurement of Mal d 1 apple allergen content was achieved by ELISA method.

Fig. 2 shows the Mal d 1 from apples as effected by organic farming and integrated cultivation technology.

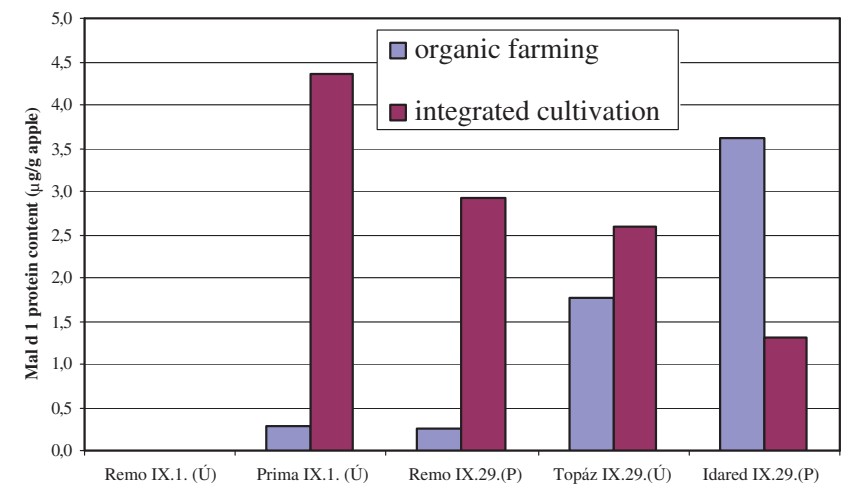

Figure 2. Protein content of Mal d 1 allergen fraction from apple cultivated under organic farming and integrated condition
The data on Fig. 2 show that in general apple harvested from trees of organic farming, except those from Idared IX.29. (P) variety, contains less Mal d 1 allergen content than that of apples grown under integrated cultivation conditions. Apple fruits from Idared IX.29. (P) cultivated with organic farming, contained more allergenic protein than the fruits from the same variety but grown under integrated cultivation conditions. This should be taken into consideration when such variety is to be used as raw material for apple-based food industries. It is of special interest from nutritional point of view that by using ELISA method no Mal d 1 was detected in fruits of Remo IX.1. (Ú) variety, while the same variety of Remo, but from other area (Remo IX.1. (P)) had Mal d 1 content.

The differences, in Mal d 1 content, between the different apple varieties grown under integrated treatment can be seen in Fig.3.

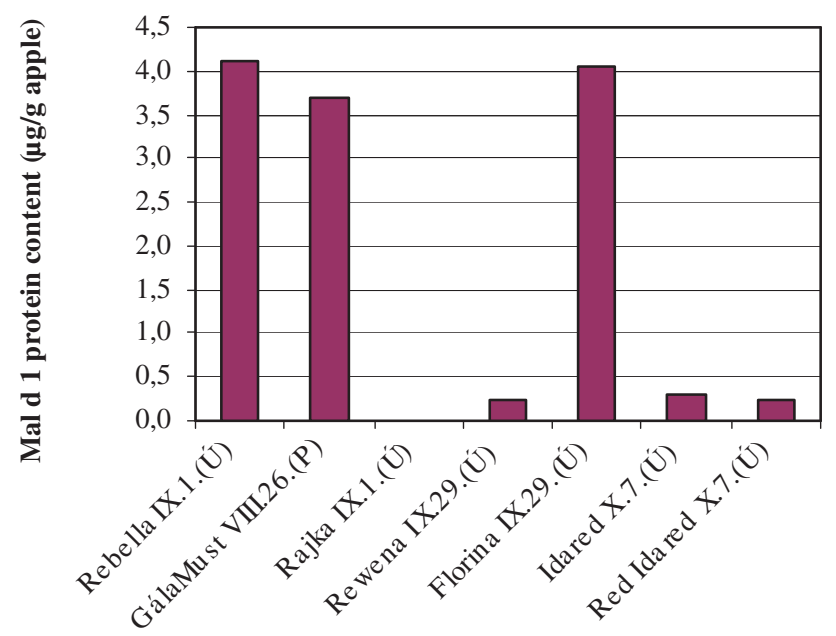

Figure 3. Protein content of Mal d 1 allergen fraction from different apple varieties cultivated under integrated condition

Rebella GálaMust Rajka Rewena Florina Idared and Red Idared.

Rebella IX. 1. (Ú), GálaMust VIII. 26. (P), and Florina IX. 29. (Ú) have the highest level of Mal d 1 allergen, while Rewena IX. 29. (Ú), Idared X. 7. (Ú) and Red Idared Újfehértó X. 7. (Ú) has only small concentration of Mal d 1, less then $0.5 \mathrm{mg} / \mathrm{g}$ apple. Rajka IX. 1. (Ú) seemed to be the less 
dangerous specie related to the allergenic risk of Mal d 1 allergen, because Mal d 1 protein was not detected by ELISA.

It is interesting to mention that Idared grown under integrated condition, but at different cultivation area (Idared IX. 29. (P) and Idared X.7. (Ú) showed high and low level of Mal d 1, respectively (Figs. 1 and 2).

These examinations warn the apple allergic patients to avoid the allergy-causing species. Moreover with our results we can draw the plant breeders' attention to the possibility for cultivating apple species with low allergenic risk. These results lead to the consequence that the cultivation condition can cause changes in allergenic content.

In order to have more real view on the allergic activity of apple and how such activity is affected by the technology of cultivation, it is necessary to determinate other major allergen content such as Mal d, which is our target in research plan to be conducted in the near future.

\section{References}

Hoffmann-Sommergruber, K. (2000): Plant allergens and pathogenesis-related proteins. What do thye have in common? International Archives of Allergy and Immunology. 122: 155-166.

Mills, E.N.C. \& Breiteneder, H. (2005): Food allergy and its relevance to industrial food proteins. Biotechnology Advances. 23: 409-414.

Viets S., Schöning, B. \& Jankiewicz, A. (1993): Occurrence of IgE binding allergens during ripening of apple fruits. Food and Agricultural Immunology. 5: 93-105. www.allallergy.net

Tijssen, P. (1985): Laboratory techniques in biochemistry and molecular biology. Practice and theory of enzyme immunoassays. Eds.: Burdon R. H., van Knippenberg P. H., Amsterdam, The Netherlands: Elsevier Science Publishers Biomedical Division (5 th edition). 549. p.

Harboe, N. \& Inglid, A. (1973): Immunization, isolation of immunoglobulins, estimation of antibody titre. Scandinavian Journal of Immunology, 2 (Suppl 1): 161-164. 